\title{
Instructional Experiment Of Practical Competencies-Oriented Teaching Materials In Technical Universities
}

\author{
Su-Chang Chen, National Penghu University of Science and Technology, Taiwan
}

\begin{abstract}
This study aims to conduct experimental instruction on the human resource management unit of business management in practical competencies-oriented business program developed by Chen (2005). This study is based on the quasi-experiment method and the subjects are two classes of students in a four-year technical university who have completed the two-credit "Management" class in the previous semester. Experimental results showed that the teaching materials and supplementary cases can enhance students' learning achievement; however, problem-solving attitude is not significantly improved.
\end{abstract}

Keywords: Practical Competencies, Teaching Materials, Technological and Vocational Education, Technical Universities

\section{INTRODUCTION}<smiles>[C]1C=CCCC1</smiles>
chool education is closely related to social demands. The technological and vocational system in Taiwan, therefore, includes vocational schools, junior colleges and technical universities (Hsiao et al., 2009). The educational system is in response to the combination of historical transition, social perspectives, economical advancement and people's expectation of society (Hsiao \& Chen, 2004). Chang (1998) considered that technological and vocational education should head for the direction of high-qualitative life, technology progress, productivity upgrade, manpower requirement, economical development, and modernization to greet the epochmaking approach of the high-tech age. Lee (1999) thought that the mission of the technological and vocational education system across the century was to prevent the enterprise manpower from running short and to promote competitiveness in the enterprises. Yung (1985) deemed that technological and vocational education instructs skills for employment and values practice and cooperation with industrial and business circles. Technological and vocational education emphasizes on practice-oriented courses, integrated classroom lecture, practice in training place, and job training in order to meet educational concept of school to work. Blanchard (2003) considered that technological and vocational education needs to serve to demonstrate the abilities of educators to deliver work-ready training, converting the youth of today into tomorrow's technology-oriented labour force. It needed to develop the manpower for the work field and the setting of its departments regarding field jobs, instead of scholarship research as the core curriculum (Hsiao \& Chen, 2001, 2004). Lin and Chang (1998) suggested that technical universities should cultivate graduates with professional practical ability. Thus, reform of curriculum, teaching materials and instructing method with time and social and economic changes is a critical issue for technical universities at the present time. Fan (1999) indicated that technological and vocational education aims to cultivate technical talents needed in society. It emphasizes on practical instruction and orientation, values the content and process of cognition, and the curriculum design should support the features of technology in order to enhance students' practical experience and creativity. Thus, Wu (1999) suggested that in promotion of refined technological and vocational education, it is important to emphasize the development of curriculum and teaching materials in order to cultivate students' competencies in the labour market. How to cultivate the talents needed by the industry becomes the key of education in technical universities. Teachers in technical universities are thus responsible for developing teaching materials and instructing the method involving practice. Upon recommendation of General Chamber of Commerce of the Republic 
of China and The Congress of Association of Secretaries and Administrative Professionals (CASAP), the former study by Chen (2005) invited 30 experienced supervisors and personnel from the business circle to participate in three Delphi questionnaire surveys. The results were used to conclude the 70 professional and practical competencies needed by graduates of the business program in technical universities in the workplace. It had transformed the competencies into 15 courses and designed teaching material according to analytical result (Chen, 2005). Will the teaching materials be suitable for students in technical universities? It is the first motivation of this study.

Curriculum development in Taiwan was usually established through teachers' views and didn't focus on the needs of the industry (Chen, 2006; Lin, 1994). As a result, most students learned portion rather than integration of the field and had much more theoretical knowledge rather than practical technology (Hsiao \& Chen, 2001, 2004). There exits a disparity between technical universities' curriculum and the needs of the industries (Chang, 1998). It means that teaching in technical universities has caused some problems, which are more theory-oriented rather than practice-oriented. It seems difficult to cultivate qualified students who need more sound academic foundation courses (Chen, 2006; Hsiao \& Chen, 2004). Traditional instruction is teacher-oriented; i.e., systematic lecture might limit knowledge transfer and generalization since knowledge in textbooks cannot be connected with reality and it will lead to inert knowledge. Thus, "discussion lecture" has gradually replaced "pure lecture". Discussion lecture can facilitate teacher-student discussion in class. It enhances students' participation and also meets students' learning progress and triggers their learning interests. Teaching materials of the case study are based on a real situation, allowing students to experience the actual business operation and exercise their analytical ability (Liu, 2009). Will the approach be suitable for students in commercial program at technical universities? It is the second motivation of this study.

\section{PURPOSE}

This study aims to determine if local case teaching materials in Taiwan developed by Chen (2005) can enhance students' learning achievement and problem-solving attitude.

\section{METHOD}

This study adopted the quasi-experiment method. The experimental group included 31 freshmen students in the Department of Applied Foreign Languages of National Penghu University of Technology and the control group comprised of 46 freshmen students in the Department of Marketing and Logistics Management at the same school. The participants completed the two-credit "Management" class during the previous semester. The experiment was conducted in the course unit of "Human Resource Management" during the second semester. The control group received a traditional lecture, whereas the experimental group received teaching materials and local case of human resource management by Chen (2005). The experimental instruction lasted for three weeks.

Prior to the experiment, a pre-test was conducted to determine the problem-solving attitude and pre-learning outcome of the two groups. After the three-week experiment, a post-test was conducted to determine the difference between the problem-solving attitude and learning outcome.

The evaluated questionnaire was used in this study. The first section was problem-solving attitude and was based on a scale modified by Chang (1999), which included 37 items. Cronbach's $\alpha$ of the whole scale was 0.877 . Re-test reliability of three weeks was 0.883 . According to the factor analysis, the construct validity was acceptable and met the framework of the original scale. The second section was learning outcome consisting of 40 items pertaining to the learning objectives. After the experiment, the researcher made minor revisions to the number of items and conducted a post-test.

\section{RESULT}

A pre-test was conducted to determine the difference of academic performance and problem-solving attitude on "Human Resource Management" of the two groups. According to Table 1, the two groups do not reveal significant difference regarding learning achievement or problem-solving attitude, indicating that the two groups can participate in comparative instructional experiment. 
Table 1: $t$ Test of Pre-test Performance

\begin{tabular}{|l|l|c|c|c|c|c|}
\hline \multicolumn{2}{|c|}{} & $\mathbf{N}$ & $\mathbf{M}$ & SD & t-value & p-value \\
\hline \multirow{2}{*}{ Learning Achievement } & experimental group & 31 & 23.548 & 6.824 & \multirow{2}{*}{0.784} & \multirow{2}{*}{0.436} \\
\cline { 2 - 6 } & control group & 46 & 24.837 & 7.234 & & \\
\hline \multirow{2}{*}{ Problem-solving Attitude } & experimental group & 31 & 79.23 & 7.73 & 0.318 & 0.752 \\
\cline { 2 - 5 } & control group & 46 & 79.93 & 10.67 & & \\
\hline
\end{tabular}

According to Table 2, a t test showed that the learning achievement of the experimental group is significantly better than the control group and it reaches significance level (0.01). It indicates that the teaching materials and supplementary case can enhance students' learning outcome. However, regarding the problem-solving attitude, the two groups do not reveal a significant difference.

Table 2: t Test of Post-test Performance

\begin{tabular}{|l|l|c|c|c|c|c|}
\hline \multicolumn{2}{|c|}{} & $\mathbf{N}$ & $\mathbf{M}$ & SD & t-value & p-value \\
\hline \multirow{2}{*}{ Learning Achievement } & experimental group & 31 & 39.371 & 10.921 & \multirow{2}{*}{$2.655^{* *}$} & \multirow{2}{*}{0.010} \\
\cline { 2 - 6 } & control group & 46 & 32.989 & 9.939 & & \\
\hline \multirow{2}{*}{ Problem-solving Attitude } & experimental group & 31 & 78.52 & 6.69 & 1.021 & \multirow{2}{*}{0.310} \\
\cline { 2 - 6 } & control group & 46 & 80.48 & 9.17 & & \\
\hline
\end{tabular}

According to Table 3 and t test, the learning achievement of the experimental group after the experiment has significantly improved and it reaches significance level (0.01). It demonstrates that teaching materials and supplementary case can enhance students' learning outcome. However, regarding problem-solving attitude, there is no significant difference before and after the experiment.

Table 3: $t$ Test of Before and After Experiment for Experimental Group

\begin{tabular}{|l|l|c|c|c|c|c|}
\hline \multicolumn{2}{|c|}{} & $\mathbf{N}$ & $\mathbf{M}$ & $\mathbf{S D}$ & t-value & p-value \\
\hline \multirow{2}{*}{ Learning Achievement } & before experiment & 31 & 23.548 & 6.824 & \multirow{2}{*}{$6.841^{* *}$} & \multirow{2}{*}{0.000} \\
\cline { 2 - 7 } & after experiment & 31 & 39.371 & 10.921 & & \\
\hline \multirow{2}{*}{ Problem-solving Attitude } & before experiment & 31 & 79.23 & 7.73 & 0.387 & 0.700 \\
\cline { 2 - 6 } & after experiment & 31 & 78.52 & 6.69 & & \\
\hline
\end{tabular}

\section{CONCLUSION AND DISCUSSION}

The curriculum development, teaching materials, and instructing method for business program in technical universities didn't comply with social development and change. This situation results in complaints from industries regarding technical universities graduated students not doing well for their requirements. This is the major linking problem between companies and technical universities in Taiwan. In order to solve this problem, curriculum development, teaching materials, and instructing method for the business program in technical universities should be practical oriented (Chen, 2006).

The experimental result of this study reveals that teaching materials and supplementary case can enhance students' learning outcome. It apparently encouraged the result of Chen (2005) former research. However, since this study only focuses on one subject, the inference is limited. Moreover, a problem-solving attitude is the key factor to solve practical problems in the business circle. However, experimental result shows that teaching materials cannot enhance problem-solving attitude, indicating that the approach cannot improve students' problem-solving attitude. Future studies can probe into this aspect.

For future studies, it can conduct experimental instruction on the 15 courses developed by Chen (2005). In addition, since practical teaching material can enhance students' learning outcome, it is suggested that technical 
universities' teachers can design appropriate textbooks based on the teaching materials developed by Chen (2005) according to students' levels in their schools so that the level, depth and scope of teaching content will meet students' needs. Moreover, the characteristics of the departments can be developed.

\section{ACKNOWLEDGEMENTS}

The author would like to acknowledge the financial support of the National Science Council, Republic of China for the contract number of NSC 93-2516-S-346-001.

\section{AUTHOR INFORMATION}

Su-Chang Chen Dr. is an associate professor and department chairman at the department of Marketing and Logistics Management in National Penghu University. He received MBA degree from institute of Management Science in National Chia-Tung University in 1972 and Ph. D. degree from the department of Industrial Education in National Changhua University of Education in 1999. His research interests include vocational and technological education, human resource management, and business administration.

\section{REFERENCES}

1. Blanchard, Wendie R., Wiring Student Certifications to Industry Careers. Techniques: Connecting Education and Careers, Vol.75, No.8, pp.26, 2003.

2. Chan, Jen C., A Study of the Influence of Problem-Solving Teaching Strategy on the Learning of Power Wiring Course for Vocational Industrial High School Students in Taiwan, Doctor Thesis of Department of Industrial Education, National Changhwa University of Education,1999.

3. Chang, Tien. G., Curriculum and Teaching of the Technical Vocational Education in the High-Tech Society, Technical-vocational Education Bimonthly, No.43, pp.13-15, 1998.

4. Chen, Jun T., Theories and Practice of Case Teaching, Personnel Monthly, Vol.47, No.4. pp.42-46, 2008

5. Chen, Su C., Commercial Program Design for Department of Applied Foreign Languages in Technical Institute. Proceeding of 2005 Hawaii International Conference on Education, pp.688-697. 2005.

6. Chen, Su C., Developing a Practical Competency Curriculum for Department of Marketing and Logistics Management in Technical University, Proceeding of 2006 IEEE International Conference on Service Operations and Logistics, and Informatics, pp.203-208, 2006.

7. Fan, Li H., The Curriculum Needed of Stock Financial Industry in the Department of financial technique, Kun Shan College Journal, No.2. pp.105-112, 1999.

8. Hsiao, Hsi C. \& Su C. Chen, Process of Curriculum Development for Engineering Education. $2^{\text {nd }}$ Russian Seminar on Engineering Education, UICEE: Tambov, Russia. pp.27-29, 2001.

9. Hsiao, Hsi C. \& Su C. Chen, The Role of Technological University in Vocational and Technological Education in Taiwan, International Journal of Technology and Engineering Education. Vol.1, No.1, pp.7384, 2004.

10. Hsiao, His C., Chen, Su C., Chang, Jen C., Shen, Chien H. and Chun M. Chou, Comparison of School Organizational Innovation Indices in Technical Education System of Taiwan. The International Journal of Technology and Engineering Education, Vol.6, No.2, pp.1-9, 2009.

11. Lee, Long S., Ideal and Design of the Iintegrative Curriculum of the Technical and Vocational Education, Technical-vocational Education Bimonthly, No.54, pp.14-19, 1999.

12. Lin, K., A Study of Vocational Competence for Shipping and Transportation Workers, Shipping Quarterly. Vol.3, No.1, pp.27-43, 1994.

13. Lin, Teng J. and Shao S. Chang, The Development Trend of Technological and Vocational Educations, Technical and Vocational Education Bimonthly, N0.43, pp.6-12,1998.

14. Liu, Chang Y., The Case Teaching in Management Education. 2010/04/09 retrieved from http://www.cyut.edu.tw/ crissa/class_file/97-2/teaching/article/20090302-26.doc.

15. Wu, Ching J., Promoting Refined Technical Education, 30 year special issue of Department of Technological \& Vocational Education, Ministry of Education, Republic of China. pp.75-85, 1999.

16. Yung, Chaur S., Theories and Practice of Technical and Vocational Education, Taipei: San Min Book Co., Ltd., 1985. 